\title{
O contexto das manifestações populares na copa das confederações: entre o dizer e o silenciar
}

\author{
The Context of Popular Protests During \\ the Confederations Cup: Between Saying \\ or Hushing
}

Micheline Mattedi Tomazi*

Universidade Federal Do Espírito Santo

Vitória - Espírito Santo / Brasil

RESUMO: Este artigo tem como objetivo analisar a canção Cálice, de Chico Buarque, em diálogo com cartazes, presentes nas manifestações sociais no Brasil durante a Copa das Confederaçôes em 2013, que retomam a canção buarqueana. Para tanto, lançamos mão das considerações sobre o silêncio de Orlandi (1997), dos artigos de Burke (1999) e Dias (1999) e do conceito sociocognitivo de contexto de van Dijk (2001; 2010; 2012). Pretendemos analisar o emprego do silêncio como estratégia discursiva para burlar a censura e compreender, do ponto de vista sociocognitivo do contexto, como os indivíduos adaptam a palavra poética de resistência da ditadura à nova situação de comunicação social. Os resultados deste estudo evidenciaram que tanto as formas de silenciamento quanto a construção das estruturas discursivas não são influenciadas pela situação comunicativa, mas pelos modelos de contexto que cada indivíduo constrói em relação a determinado evento.

PALAVRAS-CHAVE: canção, manifestações sociais, modelos de contexto; silêncio.

ABSTRACT: This paper aims to analyze the song "Calice" by Chico Buarque in dialog with posters present in the social demonstrations that took place in Brazil during the 2013 FIFA Confederations Cup, which harkens back to the Chico Buarque song. For that purpose, we delve into the considerations on silence from Orlandi (1997), Burke (1999), and Dias (1999), as well as the concept of the socio-cognitive context from van Dijk $(2001,2010,2012)$. We intend to analyze the use of silence as a discursive strategy to sidestep censorship and understand, from the point of view of the socio-cognitive context, how individuals adapt the poetic word from dictatorial resistance to the new environment of social communication. The results of this study demonstrate that neither the forms of

*michelinetomazi@gmail.com 
silencing nor the construction of the discursive structures are influenced by the communicative environment, but rather by the context models that each individual constructs for a given event.

KEYWORDS: song, social demonstrations, context models; silence.

\section{Considerações iniciais}

Historicamente, somos levados a acreditar que a paixão brasileira pelo futebol se contrapõe à conscientização política (SORRENTINO, 2013). Essa crença não é nova e a estratégia de ludibriar a população com o ufanismo verde-amarelo decorre da Ditadura Militar, quando a Copa do Mundo abrandava as contestações de milhares de pessoas (CHAUÍ, 2001).

A conquista da Copa do Mundo pela seleção brasileira de futebol, desde 1958 e principalmente com a vitória de 1970, até os dias atuais, é utilizada como estratégia para se propagar e consolidar o mito do verde-amarelismo que, se surgiu com toda a força na época da ditadura militar, não deixou de se revelar ainda nos dias de hoje sob uma ideologia dominante. O futebol ganhou a alcunha de "paixão nacional" e se constituiu como marca cultural do povo brasileiro, que passou a celebrar a vitória com uma canção cujo significado foi inovador: "Noventa milhōes em ação,/ Pra frente, Brasil, do meu coração". Com o "mito do verde-amarelismo" instaurado entre nós, passou a ser comum os automóveis trazerem slogans ufanistas, as bandeiras serem penduradas nas janelas das casas, entre outras ações que colocaram em cena não só o povo brasileiro, mas também o caráter de integração nacional (CHAUÍ, 2001, p. 31).

Não obstante, a própria história do povo brasileiro nos mostra que, se somos capazes de cantar a alegria do futebol, também cantamos a tristeza da repressão e da dominação. Nesse sentido, a passagem da famosa canção Cálice, produzida em 1973 por Chico Buarque em parceria com Gilberto Gil, cujo refrão diz "Pai! Afasta de mim esse cálice" (CHEDIAK, 1999) serve como exemplo de canção na qual a voz é de um enunciador que clama diante do sofrimento na época da ditadura militar. Esse período nos deixou, além das lembranças de sangue e exílio, um grande legado de resistência, pois foi um momento extraordinariamente marcado por debates em torno do engajamento revolucionário da palavra poética, palavra que, naquela ocasião, constituía um instrumento de luta pela voz que fora silenciada.

Curiosamente, a voz que clamou e foi calada é recuperada no contexto atual das manifestações no Brasil. Noutros termos, o mundo que foi contado e cantado na canção buarqueana, em 1973, é retomado pela população nos 
movimentos sociais durante a Copa das Confederaçôes, em cartazes que trazem trechos da referida canção como uma forma de reivindicação. Se, nos anos de chumbo, a juventude intelectual acreditava na força da arte vinculada ao engajamento político-social, em 2013, também a juventude, encorajada pela luta precedente e, novamente pela força da arte e da palavra, engaja-se numa batalha pela voz.

É nesse sentido que apresentamos uma análise acerca da referida canção em diálogo com dois cartazes presentes nas passeatas no Brasil durante a Copa das Confederaçôes, no dia 21 de junho de 2013. Pretendemos com esta análise não só propor o diálogo da retomada entre textos em contextos distintos, mas também discutir as formas de silenciamento presentes na canção, buscando refletir sobre como os indivíduos adaptam a palavra poética de resistência da ditadura à situação de comunicação social das reivindicações.

Assumimos, neste artigo, que o papel simbólico do futebol em nosso país contribuiu de forma significativa para as manifestações de junho de 2013, não só porque os protestos eclodiram durante a Copa das Confederações, mas, principalmente, porque a tentativa dos manifestantes cariocas para chegarem ao novo estádio do Maracanã, a resistência e a força da polícia em deixá-los seguir rumo ao estádio, deu ao tema do futebol a transcendência necessária para passar da sua inscrição na jurisdição ideológica da "falsa consciência" para a conscientização política (SORRENTINO, 2013). Esse cenário dos protestos no Rio de Janeiro produziu não só novas adesões às manifestações, mas a solidariedade e a indignação dos brasileiros de outros estados. Portanto, como simbologia e patrimônio coletivo de nosso povo, o futebol deixou de ser visto por muitos como "ópio do povo" para ressignificar, reafirmar-se como arena de lutas para a afirmação cultural de nossos desejos coletivos em prol de um país sem corrupção.

Para desenvolvermos o presente artigo, procuramos, respeitando as diferenças de abordagens discursivas dos autores, promover um diálogo entre as noçôes de silêncio de Orlandi (1997), de Burke (1999), de Dias (1999), com o conceito sociocognitivo de contexto de van Dijk (2001; 2010;2012).

A escrita deste artigo segue o seguinte percurso: na primeira parte, fazemos uma breve retomada dos contextos da Ditadura e das manifestações sociais durante a Copa das Confederações no Brasil, discutindo as formas de reivindicação usadas nos dois momentos. Nos tópicos seguintes, intitulados "Quando o silêncio fala" e "O dizer e o silenciar: uma questão de contexto" apresentamos as formas de silenciamento e a noção cognitiva do contexto como ferramentas para análise da canção buarqueana e dos cartazes das 
manifestações. Na seção subsequente, realizamos a análise dos textos propostos neste artigo, buscando articular as teorias de silêncio e de contexto, a fim de chegarmos a conclusões sobre como as estruturas sociocognitivas de uma situação de comunicação se relacionam com as estruturas discursivas desse evento.

\section{Os rostos e as vozes das lutas sociais no Brasil: retomando os contextos}

As lutas sociais no Brasil possuem um caráter histórico peculiar: têm um rosto e uma voz. O rosto é pintado com as cores verde e amarela ou mascarado, e a voz, essa pode ser escrita, ouvida ou não, acompanhada com ou sem os acordes de um violão, porém possui uma força imensurável, capaz de ecoar por várias gerações.

O Golpe Militar de 1964 representou para o Brasil uma severa ruptura do processo de construção de uma democracia e, consequentemente, o apagamento de muitas vozes. Imediatamente após a tomada do poder pelos militares, foi instituído o Ato Institucional I (AI) e confiscados os direitos até então adquiridos. Os partidos políticos foram dissolvidos e adotou-se um sistema bipartidário. A liberdade de expressão, os sindicatos, os movimentos estudantis, dentre outras organizações que representavam a sociedade foram quase extintas. O Brasil, entre os anos de 1964 a 1985, viveu sob o comando do regime ditatorial, estigmatizado por intransigência, censura, tortura e desaparecimentos. Esse período histórico "foi marcado por uma chuva de decretos-lei, atos institucionais e leis de segurança nacional. Enfim, um regime cujo maior objetivo era manter a ordem considerando como desordem qualquer tipo de manifestação contrária à sua" (RUFINO, 2006, p. 27).

Nesse contexto, as vozes dos jovens, asfixiadas nos movimentos de luta de classe, passaram a ser ouvidas através da Música Popular Brasileira (MPB). A MPB ganha as massas e a palavra revolucionária vai amotinando o clamor da população. Contudo, a palavra poética começou a ser vista pelos censores como uma ameaça à "ordem" e as cançôes passaram a ser censuradas e impedidas de serem veiculadas. $\mathrm{O}$ censor atacava a escrita, incitava o medo no autor e gerava uma "neurose" do silêncio, instaurando a autocensura - quando o medo de falar se torna igual à necessidade de se manter calado. Surgem, então, as falas enviesadas que buscavam o aproveitamento da linguagem escrita e cantada, por meio das letras, para fazer falar os silêncios da linguagem (TOMAZI, 2008). 
Com a intenção de silenciar a luta da população brasileira contra os exílios, as torturas e a censura da ditadura, o presidente Médici investiu na publicidade da Copa do Mundo, em 1970, com a veiculação de slogans como "Brasil, ame-o ou deixe-o", "Pra frente Brasil" e "Ninguém segura este país", que buscavam direcionar a população a um forte patriotismo, além de propagar o "Milagre econômico" vivido na época.

Alguns discursos silenciados na ditadura foram retomados nas manifestaçōes durante a Copa das Confederações no Brasil, que teve início em 15 de junho de 2013, para contestar o aumento das tarifas do transporte público em Porto Alegre, São Paulo e Rio de Janeiro, organizados, principalmente, pelo Movimento Passe Livre (MPL). Após a repressão policial contra os manifestantes, os movimentos ganharam apoio popular e os manifestantes passaram a questionar uma grande variedade de problemas nacionais, tais como as obras superfaturadas dos estádios para a Copa do Mundo, a falta de investimentos na educação e na saúde, a corrupção política e a possibilidade de aprovação da PEC 37 (Proposta de Emenda Constitucional 37/2011 elaborada pelo deputado Lourival Mendes, que pretende limitar o poder de investigação criminal a policiais federais e civis).

Observamos que as vozes de reivindicação da população nas passeatas nacionais ocorridas na Copa das Confederaçôes se unem em gritos de guerra e em cartazes que são carregados pela multidão. $O$ cartaz, assim como a canção, é um instrumento de luta. De modo particular, os cartazes escolhidos para análise neste artigo poderiam ser chamados de cartazes-canção, pois os textos, carregados de maneira erguida e militante nas ruas, clamam novamente: "Pai, afasta de mim esse cálice."

É, pois, a partir dos direcionamentos teóricos vistos até aqui que se pretende proceder à análise da canção Cálice, a partir da leitura de dois cartazes, presentes nas manifestações sociais no Brasil, em junho de 2013, que retomam o discurso da cançáo buarqueana. Buscaremos analisar o silêncio como estratégia discursiva usada para burlar a censura e compreender, do ponto de vista sociocognitivo do contexto, como os indivíduos adaptam a palavra poética de resistência da ditadura à situação de comunicação social atual.

\section{Quando o silêncio fala}

Para Orlandi (1997), existem dois tipos distintos de silêncio: o silêncio fundador, aquele que existe nas palavras, que significa o não-dito e que dá espaço de recuo significante, produzindo, assim, as condições para significar, 
e a política do silêncio que se subdivide em silêncio constitutivo e silêncio local. Ela esclarece que o silêncio constitutivo nos mostra que, para dizer, é preciso não dizer; nesse sentido, o uso de uma palavra apaga necessariamente as "outras" palavras. Já o silêncio local é aquele que se refere à censura propriamente dita, compreende aquilo que é proibido, que não pode ser dito em uma dada conjuntura. Esse tipo de silêncio torna-se uma categoria de suma importância para a análise que se pretende com relação à voz política e social presente na composição e nos cartazes.

Em se tratando do silêncio fundador, a autora afirma que o silêncio é fundante porque ele é matéria significante por excelência, ele é "o real do discurso". Ao se referir à política do silêncio local, Orlandi (1997) esclarece que nela há o silenciamento, ou seja, a interdição do dizer, o "tirar" a palavra, obrigar a dizer o que não quer ou fazer calar. Nesse sentido, a censura do período da ditadura militar é um exemplo de silêncio local que deve ser pensado em termos de materialidade linguística e histórica (ORLANDI, 1977, p.77).

Desse modo, no fato de não se exteriorizar o pensamento, interrompê-lo, cria-se um impacto de hesitação e emoção que envolve e comove o leitor, persuadindo-o, explorando a afetividade humana; ou seja, na elocução, há uma escolha de meios para a realização dos objetivos. Assim é que, na ausência do signo verbal, outro signo entra em cena: o silêncio. Nesse sentido, várias estratégias são utilizadas: a preterição, o suspense, a litote, a elipse, a silepse, o zeugma, a reticência, recursos retóricos que podem estar ligados ao não querer dizer e ao indizível, ao que não se pode dizer e é omitido por meio de tais recursos.

As coisas que não foram ditas emergem subjacentes ao texto, conferindolhe outra dimensão; nela, uma existência subjetiva surge a partir do que foi silenciado. Dias (1999) contribui dizendo que a questão do silêncio na literatura assume vários níveis e, um deles, o que mais nos interessa para o âmbito deste artigo, refere-se àquilo que se silencia no texto e pode ser justificado pelo fato de o autor não se atrever a falar de algo que lhe é proibido e, ao silenciar, aquilo que é dito no texto adquire uma espécie de ambiguidade e força interior.

Burke (1999), ao classificar o(s) silêncio(s), toca nos longos ou curtos, naturais ou culturais, voluntários ou forçados, espontâneos ou estratégicos, cálidos ou frios, normais ou doentios, podendo expressar ainda sinal de discrição ou humildade. Tais características comprovariam que a ausência do falar não é fenômeno puramente negativo, mas uma arte, "a arte de domar a nossa língua"; ou seja, para Burke (1999, p. 5) "o silêncio em si é uma forma de comunicação que, como as outras formas de comunicação, tem suas próprias regras e convenções". As regras para tais leis variam de um lugar para 
outro, de acordo com o contexto social, histórico e político de cada época. Por isso, esse autor afirma que há toda uma geografia, uma sociologia e uma história envolvendo a questão do silêncio.

A noção de contexto apresenta-se, assim, como um elemento bastante relevante para o que propomos, uma vez que, para analisar as formas de silenciamento, precisamos refletir sobre o contexto. Por isso, abordaremos na seção a seguir a teoria cognitiva de contexto de van Dijk (2012).

\section{O dizer e o silenciar: uma questão de contexto}

Um discurso pode ser retomado em diferentes épocas e em diferentes esferas comunicativas. O que vai determinar o seu novo sentido são os aspectos contextuais, as instituições, a classe social, as ideologias etc. Van Dijk (2001) apresenta uma noção de contexto a partir da interface entre as estruturas de situaçóes sociais e as formas como os atores sociais representam mentalmente essas situações, buscando compreender como essas representações podem influenciar na produção e compreensão do discurso. Assim, a teoria do contexto explica como os participantes são capazes de adaptar a produção, recepção e interpretação do discurso à situação de comunicação social. Nesse sentido, não é a situação social comunicativa que influencia na construção das estruturas discursivas, mas a representação mental de cada participante.

Van Dijk (2012) propõe o conceito teórico de que contextos são construtos subjetivos dos participantes, ou definiçôes subjetivas das situações interacionais ou comunicativas. Desse modo, os contextos são experiências únicas, nos quais aparecem as experiências vividas pelo corpo, percepções, emoções referentes à situação comunicativa em curso. Assim como os contextos são únicos, as formas de se utilizar a linguagem também o são, por isso os discursos são únicos. Van Dijk (2012) esclarece que os construtos dos participantes, subjetivos, embora socialmente fundamentados, são construídos a respeito das propriedades que para eles são relevantes em tal situação, isto é, modelos mentais. Desse modo, os indivíduos não estão apenas envolvidos em processar um discurso, mas engajados em construir dinamicamente sua análise e interpretação subjetiva on-line (VAN DIJK, 2012).

Além da representação do sentido de um texto, os usuários de uma língua constroem modelos mentais dos eventos que são assunto desses textos, isto é, a situação que eles têm como denotação ou referência. Por isso, os modelos mentais são representações cognitivas de nossas experiências e possuem, segundo van Dijk (2001), categorias contextuais gerais como: cenário (tempo, lugar), 
participantes e um evento ou ação. A marca de tais categorias no discurso pode ser identificada pelas descrições indexicais (VAN DIJK, 2010).

A diferença entre situação social e contexto é que contexto não é algo externo, fora dos participantes, mas sim algo construído por eles a partir de um modelo mental específico chamado de modelo de contexto ou apenas contexto. Segundo van Dijk (2001), como todos os modelos mentais, o modelo de contexto não representa todos os aspectos pessoais ou sociais da situação comunicativa, mas apenas os aspectos que em um dado momento são relevantes para cada participante. Logo, as estruturas discursivas serão limitadas pelas categorias da situação comunicativa como a situação corrente (hora, localização), circunstâncias correntes (o que está sendo discutido) e os vários papéis dos participantes.

Ao partirmos para a relação texto e contexto, percebemos que a contextualização é um elemento fundamental para o entendimento das atividades humanas, principalmente considerando que os con-textos são assim chamados porque, etimologicamente, eles vêm junto com os textos (VAN DIJK, 2012). Nessa esteira, os textos são incompletos e inacabados, pois, quando um indivíduo escreve, fala ou silencia pressupõe que o leitor faça inferências, acionando seus modelos de contexto para que haja o entendimento do que se quer dizer.

Segundo essa perspectiva cognitivista, entendemos que a teoria do contexto ajuda a compreender como as estruturas sociocognitivas de uma situação de comunicação se relacionam com as estruturas do discurso desse evento. Isso implica compreender vários aspectos do discurso, como a percepção individual e variável da situação de comunicação, escolhas lexicais, silenciamento, entre outros, segundo cada indivíduo.

\section{A palavra poética como forma de manifestação}

Entre as diversas manifestações artísticas emanadas na Ditadura Militar estão as canções de Chico Buarque. As composições, que simbolizavam uma forma de repúdio e luta contra as ações do governo vigente, tentavam driblar a censura num jogo que oscilava entre o dizer e o silenciar. A composição de Cálice foi feita em parceria com Gilberto Gil e, como já mencionado, essa canção se insere no contexto da censura ditatorial. O refrão teria sido escrito em uma sexta-feira da Paixão, por Gilberto Gil, que se disse influenciado pela ideia do calvário de Cristo e do "cálice" de vinho que alude ao pedido de súplica de Jesus ao Pai. Ao apresentá-lo a Chico Buarque, a paronomásia de Cálice foi 
logo percebida pelo compositor, já que essa palavra também podia ser entendida como a forma verbal "cale-se". Neste estudo, optamos por nos deter especialmente na análise do refrão da canção Cálice, ${ }^{1}$ de 1973 , em diálogo com dois cartazes das manifestações sociais no Brasil.

Vejamos, então, o refrão da canção Cálice:

\section{Pai, afasta de mim esse cálice \\ Pai, afasta de mim esse cálice \\ Pai, afasta de mim esse cálice \\ De vinho tinto de sangue}

Em diálogo com o refrão acima, surgem, na Copa das Confederações, os cartazes dos movimentos sociais no Brasil que trazem à baila a canção buarqueana, retomando seu refrão. Os dois cartazes que serão descritos abaixo foram retratados por meio de fotografias feitas durante as manifestaçōes e coletadas nos sites Uol e Terra, respectivamente. A primeira imagem foi feita em 21 de junho de 2013, no estado de São Paulo, e a segunda, também em 21 de junho de 2013, é apresentada sem indicação do local.

O primeiro cartaz, publicado no site Uol, está escrito em letras garrafais em cartolina com fundo branco por uma manifestante. Apresenta as palavras Brasil e Cálice grifadas e grafadas em cor preta com tamanho destacado em relação aos outros dizeres. A outra parte do refrão (afasta de mim este cálice) está grafada em letras menores e em cor azul. A imagem abaixo procura representar essa descrição do cartaz:

\section{QUADRO 1}

Tentativa de reprodução do cartaz divulgado no site UOL

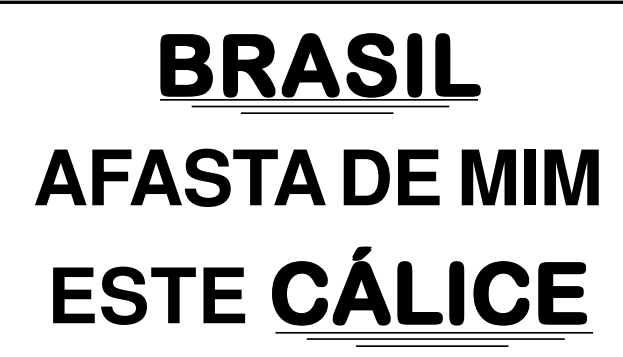

\footnotetext{
${ }^{1}$ A letra completa da canção Cálice pode ser vista ao final do artigo, no Anexo. Para um estudo mais detido acerca de toda a canção, indicamos a obra de Tomazi (2008).
} 
O segundo cartaz, divulgado no site Terra, está sendo carregado por um manifestante e apresenta o refrão da canção em letras garrafais em cor azul, com grifos em todas as palavras e um destaque maior para a palavra "cala-se". A imagem abaixo procura representar esse cartaz:

\section{QUADRO 2}

Tentativa de reprodução do cartaz divulgao no site Terra

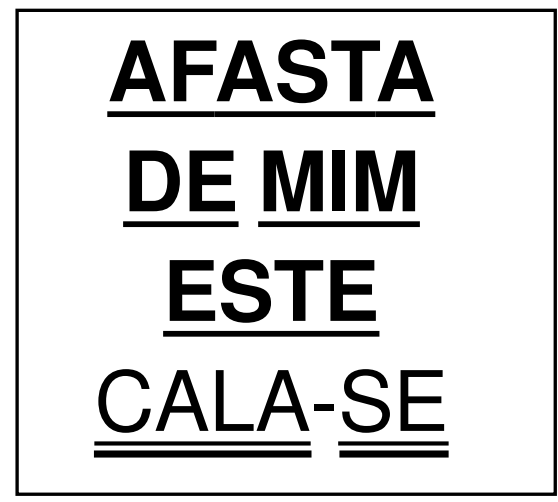

A leitura da canção e dos cartazes nos faz refletir que a linguagem que evoca e convoca o sujeito a falar é a mesma nas duas situações discursivas e o que as diferencia é apenas o contexto, uma vez que os modelos de contextos dos sujeitos de 1973 são diferentes dos modelos de contextos dos sujeitos de 2013. Contudo, ambos utilizam estratégias linguísticas para moldar o seu discurso como uma forma de adaptação à situação de comunicação social, como a escolha do tema a ser "cantado", o léxico utilizado, as estruturas sintáticas, a partir de seus modelos de contexto. Além disso, as estruturas discursivas serão limitadas pelas categorias da situação comunicativa, como a situação corrente, as circunstâncias correntes, os vários papéis dos participantes, entre outras categorias.

Um exemplo de adaptação feito pelo enunciador da canção é a escolha do vocábulo "Cálice" = cale-se, em que um "vocativo" representado pelo estrato fônico do substantivo está associado a um pedido de silêncio. Há quase um recurso "lexical" silenciado no nome "cálice" que chega a ser um trabalho significante e metalinguístico. Ao se referir ao silêncio da censura, tomando agora seu espaço ideológico, o enunciador ratifica que a proibição de falar fez germinar o interesse pela linguagem que passou a ser "sentida" como instrumento de poder. De fato, parece ser esse o procedimento utilizado na produção de Cálice, em que se pode perceber que o silêncio da censura excita 
o silêncio da cesura e, dessa forma, os espaços vazios da linguagem aparecem como lugares onde a liberdade toma fôlego e permanece.

Os enunciadores das manifestaçôes durante a Copa das Confederações também lançaram mão de estratégias linguísticas para realizar suas reivindicaçóes. Contudo, a estratégia de luta atual foi adaptar a palavra poética de resistência da ditadura à situação de comunicação. Noutros termos, os indivíduos das manifestaçôes atuais constroem modelos mentais dos eventos que eles têm como denotação ou referência, neste caso, a ditadura. Por isso, o fato de o refrão da canção buarqueana ter sido retomado nos cartazes é explicado a partir da noção de modelos mentais, conforme van Dijk (2001), em que estes se apresentam como representações cognitivas de nossas experiências e por isso possuem as categorias de cenário, participantes e um evento ou ação. Assim, quando os textos dos cartazes aludem ao refrão da canção Cálice, os enunciadores retomam o cenário da ditadura para criticar a situação política atual.

Dentre as várias leituras que podem ser feitas da palavra "Cálice", podemos destacar a que é direcionada pelo estrato semântico metafórico em que ocorre a transição inesperada e surpreendente de um outro signo, "cale-se". Essa estratégia foi empregada pelo enunciador com o intuito de desviar a censura. Percebe-se que, na canção, as palavras tornam visível o discurso do silêncio, sobretudo em termos "dramáticos", já que o significante "cálice" representa "cale-se". De fato, o silêncio do "cale-se" no "cálice" pode ser escutado pelo efeito da paronomásia criada pela oposição semântica que repousa sobre a coincidência em uma palavra que aponta para outra de sentido diferente em seu estrato fônico, pela homofonia e pela relação segmental som/ sentido. Desse modo, as palavras fazem com que, ultrapassando esse silêncio, chegue-se ao resgate dos sentidos expressos no texto. Parece viável assumir com Orlandi (1997, p. 33) que o silêncio não fala; ele é, ele significa; "no silêncio, o sentido é”, o silêncio é a condição do sentido.

A duplicidade de sentido é uma estratégia discursiva utilizada pelos compositores para burlar a censura. Assim, a estratégia em Cálice/cale-se buscou ultrapassar a mudez imposta pela ditadura, "a canção do silêncio imposto, do silêncio assumido à revelia", do silêncio que se torna progressivo e contaminador (MENESES, 2000, p. 91) para deixar entrever um recurso significativo de processo de interdiscursividade, marcado pelo interesse do homem brasileiro que se encontra privado de liberdade.

Um resumo das estratégias linguísticas acerca das palavras "cálice/calese" pode ser visto no quadro a seguir: 


\section{QUADRO 3}

Estratégias linguísticas lexicais

\begin{tabular}{|c|c|c|c|}
\hline Estratégias & $\begin{array}{l}\text { Discurso tomado como } \\
\text { referência }\end{array}$ & Cartaz Uol & Cartaz Terra \\
\hline Linguísticas & $\begin{array}{c}\text { "Pai, afasta de mim } \\
\text { esse cálice" }\end{array}$ & $\begin{array}{c}\text { "Brasil } \\
\text { Afasta de mim } \\
\text { este Cálice" }\end{array}$ & $\begin{array}{l}\text { "Afasta de mim } \\
\text { este cala-se" }\end{array}$ \\
\hline Léxico & $\begin{array}{l}\quad \underline{\text { Cálice }} \\
\text { O estrato fônico do } \\
\text { substantivo é usado para } \\
\text { burlar a censura. O traço } \\
\text { morfológico e sonoro } \\
\text { permite a associação e o } \\
\text { jogo de significantes. } \\
\text { O enunciador se distancia } \\
\text { da situação de comunicação } \\
\text { e faz uma crítica indireta. }\end{array}$ & $\begin{array}{l}\quad \text { Cálice } \\
\text { Léxico retomado } \\
\text { com a mesma } \\
\text { grafia e sentido } \\
\text { da canção. }\end{array}$ & $\begin{array}{l}\quad \text { Cala-se } \\
\text { Processo de } \\
\text { nominalização. } \\
\text { Ao utilizar o } \\
\text { dêitico "este", a } \\
\text { forma verbal } \\
\text { pronominalizada } \\
\text { no imperativo } \\
\text { passa a substantivo. }\end{array}$ \\
\hline
\end{tabular}

Fonte: (elaborado pela autora).

O substantivo "cálice" é retomado no texto do primeiro cartaz com a mesma grafia e sentido do refrão da canção, produzindo, então, o mesmo efeito de sentido. Contudo, tendo em vista as diferentes situações de comunicação nas quais os textos estão inseridos, temos formas diferentes de silêncio: na canção, o silêncio local e, no cartaz, o silêncio fundador. Ou seja, na canção o silêncio é local, porque há um recorte entre o que pode ou não ser dito, assim, a linguagem é impregnada de censura, de interdição do dizer, pois o silenciamento é imposto pela censura. Já no cartaz, o silêncio é fundador porque se inscreve na ordem do poder dizer; por isso, esse tipo de silêncio não estabelece nenhuma divisão, uma vez que "ele significa em (por) si mesmo" (ORLANDI, 1997, p. 75). Além disso, o fato de, no cartaz, o substantivo estar marcado com letra maiúscula "Cálice" direciona o leitor para a relação intertextual, mostrando a relação de sentidos e a retomada da música pelo seu nome próprio, como maneira de fazer (re)significar a história e os sentidos censurados.

Nessa perspectiva, o silêncio se instaura como a própria condição de produção de sentido, sentidos que vão sendo decifrados no desvelamento das metáforas e polissemias. Isso pode ser confirmado se analisarmos todo o texto do cartaz: "Brasil Afasta de mim este Cálice", em que o enunciador opta pelo destaque do nome próprio Brasil, que vem isolado e não separado por vírgula nem por dois pontos, como querem nossos gramáticos, no sentido de 
funcionar como vocativo. No entanto, é o próprio destaque da palavra no cartaz que, discursivamente, permite o efeito de sentido de um vocativo com a reiteração do tu, colocando em evidência o apelo que se quer transmitir. Assim, a alteração do nome próprio "Pai" para "Brasil" pode ser lida de duas maneiras. Na primeira, poderíamos dizer que a súplica é remetida ao Brasil, ao povo brasileiro que foi às ruas para reivindicar a solução de diversos problemas sociais. Na segunda leitura, poderíamos relacionar "Brasil" ao governo e à imagem da presidente Dilma, que figurativamente representa o lugar do "Pai". Essa leitura pode, ainda, ser reforçada pela imagem do expresidente Lula que, no lugar de "Pai", garantiu o lugar de sua sucessora. Esse vínculo pode ser explicado historicamente, uma vez que o ex-presidente Lula apoiou a presidente Dilma em sua candidatura e a legitimou como representante principal do Partido dos Trabalhadores (PT) no governo federal.

Do mesmo modo, o vocativo "Pai", na canção, assume uma carga polissêmica: ele pode ser lido como uma alusão à primeira pessoa da Santíssima Trindade (Pai, Filho e Espírito Santo), ou seja, "Pai" seria uma forma de tratamento para a designação bíblica da divindade, com relação a toda a criação. Seria, então, uma evocação bíblica que traz o sentido do calvário (religioso/ político). Além disso, há o sentido de pai como criador, fundador, instituidor, causador, gerador, provedor, o que poderia conduzir a leitura desse vocativo para a figura do presidente Médici, naquele contexto, e pode, hoje, direcionar para a figura de nossa presidente.

$\mathrm{Na}$ análise do segundo cartaz, observamos que o enunciador, no texto "Afasta de mim este cala-se", faz também uma referência ao refrão, mas realiza adaptações lexicais e alterações quanto à estrutura frasal. Essas mudanças podem ser identificadas com a elipse do sujeito na frase, com o apagamento do vocativo, com o uso do verbo "afastar", no imperativo, e com a alteração do substantivo "cálice" por "cala-se". Tal modificação nos convida a refletir sobre a escolha do enunciador e o efeito de sentido criado por ela. Em um primeiro momento, a forma "cala-se" parece recuperar aquele sentido, já referido anteriormente, do estrato fônico da canção, na forma verbal pronominalizada no imperativo; no entanto, essa forma está acompanhada de um dêitico que a nominaliza, substantivando-a.

Em linha gerais, quando o enunciador do cartaz usa a forma "cala-se" acompanhada do dêitico "este", ele se aproxima da situação de comunicação, faz uma crítica direta à realidade e nos direciona, explicitamente, à localização que é a situação atual das manifestações e, ainda, às circunstâncias atuais que 
marcam os discursos que circulam junto aos manifestantes. Novamente, a diferença das enunciações esbarra no silêncio, um silenciamento local do enunciador da canção que, para driblar a censura, remete à passagem bíblica $\mathrm{e}$ se distancia da enunciação, e um silêncio fundador do enunciador do cartaz que se aproxima da situação de comunicação.

Já o apagamento do vocativo configura uma forma de silenciamento, o silêncio fundador, pois, quando o enunciador escolhe não dizer, ele cria um espaço de recuo significante, ou seja, possibilita-nos refletir sobre quem são os possíveis interlocutores a quem ele dirige o seu pedido. Poderíamos novamente apreender que esse interlocutor é o povo brasileiro ou a presidente Dilma. Se atentarmos para a estratégia discursiva que o uso ou a ausência do vocativo cria em termos de efeito de sentido nos enunciados analisados, somos obrigados a admitir que se trata de um elemento que se situa fora da oração, não fazendo, portanto, parte da rede argumental do verbo, nem do predicativo. Muito embora o vocativo não possua uma relação sintática com outro termo da oração, é na instância discursiva que a palavra "Pai" ou a palavra "Brasil" instaura o apelo ratificado pelo uso do verbo "afasta" em sua forma imperativa. É assim que, na sua função apelativa de $2^{\text {a }}$ pessoa, o vocativo está ligado ao conteúdo volitivo da forma verbal, já que, em se tratando de ordem ou manifestação de desejo endereçada à pessoa com quem falamos ou a quem nos dirigimos, não há necessidade de marcar gramaticalmente o sujeito (BECHARA, 2003).

Assim, observamos em todos os casos que o enunciador se apresenta como locutor e institui o outro no fio discursivo, deixando, pois, as marcas de subjetividade. Embora o segundo cartaz não deixe explícito o vocativo, em "Afasta de mim este cala-se", sabemos que na instância discursiva ele existe e ratifica o desejo de mudança pelo conteúdo volitivo da forma verbal. Dessa maneira, o silêncio, que atua como a não voz, chama uma outra voz que é passada ao sujeito $\mathrm{tu} /$ leitor / interlocutor para que a voz se faça realmente presente. Tal recurso parece ser a utilização de uma voz em potencial que se atualizará pelo leitor. Essa voz, então, cria uma estratégia através de uma cena que referencia uma situação social por meio de um espaço de representação de um drama (eu X tu), que aponta para a narração de uma cena, cujos protagonistas são pertencentes à sociedade. Essa cena dramatizada cria uma situação para que o interlocutor, como espectador, sinta-se tocado pela situação social e possa, talvez, investir na transformação, tanto na ditadura, como nas manifestações atuais.

Novamente apresentamos um quadro sumarizando a análise lexical, desta vez, enfatizando os vocativos. 


\section{QUADRO 4}

Estratégias linguísticas lexicais

\begin{tabular}{|c|c|c|c|}
\hline \multirow{2}{*}{$\begin{array}{l}\text { Estratégias } \\
\text { Linguísticas }\end{array}$} & $\begin{array}{l}\text { Discurso tomado } \\
\text { como referência }\end{array}$ & Cartaz Uol & Cartaz Terra \\
\hline & $\begin{array}{l}\text { "Pai, afasta de mim } \\
\text { esse cálice" }\end{array}$ & $\begin{array}{c}\text { "Brasil } \\
\text { Afasta de mim } \\
\text { este Cálice" }\end{array}$ & $\begin{array}{l}\text { "Afasta de mim } \\
\text { este cala-se" }\end{array}$ \\
\hline Léxico & $\begin{array}{l}\text { Pai } \\
\text { 1) pessoa da Santíssima } \\
\text { Trindade (vocativo } \\
\text { utilizado por Jesus Cristo } \\
\text { na hora da morte); } \\
\text { 2) presidente Médici. }\end{array}$ & $\begin{array}{l}\quad \underline{\text { Brasil }} \\
\text { 1) povo brasileiro; } \\
\text { 2) presidente Dilma, } \\
\text { que, embora seja } \\
\text { uma figura feminina, } \\
\text { representa a figura } \\
\text { do "pai". }\end{array}$ & $\begin{array}{l}\frac{\text { Apagamento }}{\underline{\text { do vocativo }}} \\
\text { 1) opta pelo não dizer; } \\
\text { 2) não marca a pessoa } \\
\text { com quem fala ou a } \\
\text { quem se dirige. }\end{array}$ \\
\hline
\end{tabular}

Fonte: Elaborado pela autora.

É importante destacar que, embora os textos dos dois cartazes retomem o discurso da canção, cada um faz uma adaptação diferente em relação aos objetivos de comunicação que se pretende atingir. Nesse sentido, ainda que a situação de comunicação em que os dois cartazes estão inseridos seja a mesma - os movimentos sociais durante a Copa das Confederações -, cada indivíduo fará a sua escolha de acordo com o seu modelo de contexto. Isso confirma a colocação de van Dijk (2001) de que não é a situação social comunicativa que influencia na construção das estruturas discursivas, mas a representação mental de cada participante. Por isso, os discursos são únicos, porque os contextos são experiências únicas, nos quais aparecem as experiências vividas pelo corpo, percepçóes, emoçóes, referentes à situação comunicativa em curso.

Permeados por marcas subjetivas, os textos analisados também chamam a atenção para o uso dos dêiticos. A dêixis constitui um instrumento para dirigir a focalização do ouvinte/leitor em direção a um item específico presente no espaço dêitico. O espaço dêitico é o próprio espaço da interação. No refrão da canção, identificamos o dêitico "esse", em que o enunciador acaba por apontar para o que está próximo do interlocutor no espaço e relativamente distante do momento da enunciação. A canção parece, então, um espaço de dramatização, de teatralização em que se encontram várias vozes. Já nos dois cartazes, a marca dêitica é o "este" em que o enunciador aponta para o que está mais perto dele mesmo e mais próximo da enunciação. Considerando que os cartazes estão inseridos no meio das passeatas, nas ruas, e constituem uma extensão das vozes 
dos manifestantes, fica claro entender que o dêitico não poderia ser outro, uma vez que o sofrimento, o calar, estava ali, ao lado do enunciador. Segundo van Dijk (2010), os dêiticos revelam o fato de os falantes estarem conscientes das categorias contextuais nas quais estão inseridos, como a localização, o tempo e os vários papéis dos participantes. Por isso, constatamos que o uso do dêitico "esse" no refrão da canção é feito por um enunciador consciente da ditadura, da possibilidade da censura e do exílio. Esse "distanciamento" do dizer é uma estratégia para desviar os olhos da censura, para direcioná-los a uma outra situação, o sofrimento de Jesus Cristo. Já o dêitico "este", utilizado nos cartazes, direciona-nos, explicitamente, à localização que é a situação corrente das passeatas e, ainda, às circunstâncias correntes que são todos os discursos de reivindicação da população. As diferentes aplicações dêiticas em cada item analisado estão apresentadas a seguir:

\section{QUADRO 5}

Estratégias linguísticas dêiticas

\begin{tabular}{|c|c|c|c|}
\hline \multirow{2}{*}{$\begin{array}{l}\text { Estratégias } \\
\text { Linguísticas }\end{array}$} & $\begin{array}{l}\text { Discurso tomado como } \\
\text { referência }\end{array}$ & Cartaz Uol & Cartaz Terra \\
\hline & $\begin{array}{c}\text { "Pai, afasta de mim } \\
\text { esse cálice" }\end{array}$ & $\begin{array}{c}\text { "Brasil } \\
\text { Afasta de mim } \\
\text { este Cálice" }\end{array}$ & $\begin{array}{l}\text { "Afasta de mim } \\
\text { este cala-se" }\end{array}$ \\
\hline Dêiticos & $\begin{array}{l}\qquad \underline{\text { Esse }} \\
\text { O enunciador aponta para } \\
\text { o que está próximo do } \\
\text { interlocutor no espaço e } \\
\text { relativamente distante do } \\
\text { momento da enunciação. } \\
\text { O enunciador apresenta-se } \\
\text { consciente da ditadura, } \\
\text { da possibilidade da } \\
\text { censura e do exílio. }\end{array}$ & $\begin{array}{l}\quad \underline{\text { Este }} \\
\text { O enunciador aponta } \\
\text { para o que está mais } \\
\text { perto dele mesmo e } \\
\text { mais próximo da } \\
\text { enunciação. Direciona- } \\
\text { nos, explicitamente, } \\
\text { à localização, que é a } \\
\text { situação corrente das } \\
\text { passeatas e, ainda, às } \\
\text { circunstâncias correntes, } \\
\text { que são todos os } \\
\text { discursos de reivindi- } \\
\text { cação da população. }\end{array}$ & 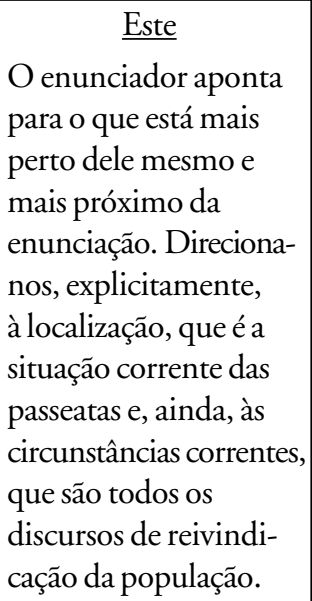 \\
\hline
\end{tabular}

Fonte: Elaborado pela autora.

Com efeito, a enunciação presente nos textos é um diálogo, cujas formaçôes discursivas e ideológicas emergem e mostram um sujeito que maneja 
a linguagem para tentar falar de seu mundo, de sua vivência. Por isso, o enunciado "Afasta de mim esse cálice" está em interdiscursividade com o discurso do cristianismo. O mesmo "parafraseia" as palavras de Cristo antes de ser preso, julgado e condenado: "Pai, se queres, afasta de mim este cálice. Contudo, não se faça a minha vontade, mas a tua" (BÍBLIA, 2000, p. 1314), insinuando um efeito paródico, dado o tom que se imprime a ele. De um tom de pedido conformado, passa-se ao tom de veemência pelo imperativo, pela ênclise do pronome e, ainda, pela reiteração do enunciado, o que poderia comprovar a leitura feita acima.

Essa interação discursiva deixa entrever o encadeamento do raciocínio; nele o discurso assume um cunho narrativo que deixa subentendidas as informaçôes de um conjunto de ações acontecidas no mundo da realidade e que são do conhecimento de todos. O enunciador, então, ao assumir a voz do povo, conclama o "afastamento de vários cálices", o da censura, o do exílio, o da fome, o da miséria, o da falta de educação, o da falta de saúde, o da corrupção, o da Copa das Confederações e de tantos outros "cálices" que torturam este país.

Dessa maneira, a mola mestra da produção de Chico Buarque dá voz a vários enunciadores que, como o de Cálice, assumem o papel de agente discursivo, conclamando a população a lutar contra as formações discursivas e ideológicas das classes dominantes.

O futebol sempre foi visto como um fenômeno social importante da cultura brasileira. A própria história desse esporte no Brasil aponta para esse fenômeno como paixão nacional, contrapondo-o a qualquer conscientização política (RAMOS, 1984). Funcionando como uma estratégia de "panem et circenses", o seu papel seria desviar a atenção e mistificar o povo, silenciandoo. Como ópio das massas, o futebol se inseriu no imaginário coletivo dos brasileiros e, assim, ele sofreu a ideologização, ao ser utilizado em diversos contextos sociais, como forma de afirmar a ideologia e o pensamento político da classe dominante. Segundo Thompson (1995), os sistemas simbólicos não são ideológicos em si mesmo, serão ideológicos dependendo da maneira como são utilizados e entendidos em contextos sociais específicos.

Nesse sentido, o fato de as manifestações terem ocorrido durante a Copa das Confederações é, acreditamos, um avanço no sentido de demonstrar que, se o futebol é uma representação cultural de nossa sociedade, é também o espaço, a arena de lutas, onde podemos nos mobilizar politicamente e cobrar ações de nossos governantes e melhoria das condições de vida. 


\section{Considerações finais}

O processo de análise do enunciado discursivo do refrão, em diálogo com os cartazes das manifestaçóes sociais, constituiu uma tentativa de interconectar os efeitos de sentido produzidos por esses discursos em diferentes situações comunicativas. Pudemos evidenciar que as formas de silenciamento estão presentes nesses enunciados e que as estruturas discursivas são construídas a partir dos modelos de evento e modelos de contexto de cada indivíduo. Uma prova disso é a diferente escolha lexical e estrutural feita pelos enunciadores em cada cartaz, embora eles tenham partido do mesmo evento como referência, o contexto da ditadura.

Por isso, compreender a relação texto-contexto é tão importante para o entendimento da atividade humana. É a partir das experiências, das percepções e dos sentimentos dos indivíduos que se constroem os discursos únicos e inacabados que, por sua vez, estarão sempre esperando as inferências do leitor para que o efeito de sentido seja alcançado.

Diante do exposto, pensamos ser importante lembrar que intensificamse, no Brasil, debates, eventos e movimentos de todos os setores para os " 50 anos do Golpe de 64”, em 2014. Dessa forma, refletir sobre as manifestações populares de 2013 pode ser uma maneira de se pensar a própria construção sócio-histórica do país, já que não só o golpe completa 50 anos, mas as eleições presidenciais e a Copa do Mundo, coincidentemente ou não, acontecem em 2014, o que nos faz refletir sobre o papel que o futebol tem assumido no Brasil. Longe de ser apenas uma modalidade esportiva, o que estamos vivenciando é a configuração do futebol como uma manifestação cultural que, em alguns momentos de nossa história, tem a função de expressar ideologicamente o desejo de nosso povo e não os valores ideológicos do poder instituído pelas elites simbólicas de nosso país.

\section{Referências}

BECHARA, E. Moderna Gramática Portuguesa. Rio de Janeiro: Lucerna, 2003. BÍBLIA. Português. Bíblia sagrada: nova versão internacional. Trad. Comissão de tradução da Sociedade Bíblica Internacional. 3. ed. São Paulo: Geográfica, 2000. BILÓ, G. Protestos em São Paulo. UOL notícias. São Paulo, 22 jun., 2013. Disponível em: <http://noticias.uol.com.br/album/2013/06/22/protestosem sãopaulo.htm\#fotoNavId=pr10372820 >. Acesso em: 15 jul. 2013. 
BURKE, P. Escutar o silêncio. Folha de S.Paulo. São Paulo, 19 set. 1999. Disponível em: <http://www1.folha.uol.com.br/fsp/mais/fs1909199904.htm>. Acesso em: 26 fev. 2014.

CHAUÍ, M. Brasil: mito fundador e sociedade autoritária. São Paulo: Fundação Perseu Abramo, 2001.

CHEDIAK, A. Songbook: Chico Buarque. Rio de Janeiro: Lumiar, 1999.

COBUCCI. L. Críticos ou divertidos, cartazes marcam a quinta-feira de protestos pelo País. Terra Cidades. São Paulo, 21 de jun. 2013. Site Terra Cidades. Disponível em: <http://noticias.terra.com.br/brasil/cidades/criticos-oudivertidoscartazesmarcamaquintafeiradeprotestospelo\%20pais, e38df256 cb66f310VgnVCM3000009acceb0aRCRD.html>. Acesso em: 15 jul. 2013. DIAS, M. S. A arte de dizer menos: entrevista com Juan José Saer. Folha de S.Paulo. São Paulo, 19 de set. 1999. Disponível em: <http://www1.folha.uol. com.br/fsp/mais/fs $1909199905 . \mathrm{htm}>$. Acesso em: 26 fev. 2014.

MENESES, A. B. Poesia e política em Chico Buarque. São Paulo: Ateliê Editorial, 2000 .

ORLANDI, E. P. As formas do silêncio: no movimento dos sentidos. Campinas, SP: Editora da Unicamp, 1997.

RAMOS, R. Futebol: ideologia do poder. Petrópolis: Vozes, 1984.

RUFINO, J. As mulheres de Chico Buarque: uma análise da complexidade discursiva de cançōes produzidas no período da ditadura militar. 2006. 146p. Dissertação. (Mestrado em Linguística) - Faculdade de Letras, Universidade Federal de Minas Gerais, Belo Horizonte, 2006.

SORRENTINO, M. A copa das manifestações, ou "Quem mexeu no meu futebol". Revista Pittacos: revista de cultura e humanidades, 2013. Disponível em: <http://revistapittacos.org/2013/07/01/a-copa-das-manifestacoes-ouquem-mexeu-no-meu-futebol/>. Acesso em: 2 fev. 2014.

TOMAZI, M. M. Cantigas de acordar: análise discursiva do enunciado poético de Chico Buarque. Vitória: Huapaya/Saberes, 2008.

THOMPSON, J. B. Ideologia e cultura moderna: teoria social crítica na era dos meios de comunicação de massa. Petrópolis: Vozes, 1995.

VAN DIJK, T. A. Algunos principios de una teoría del contexto. ALED, Revista latinoamericana de estudios del discurso, 2001, p. 69-81.

VAN DIJK, T. A. Discurso e poder. Trad. e org. de Judith Hoffnagel e Karina Falcone. 2. ed. São Paulo: Contexto, 2010.

VAN DIJK, T. A. Discurso e contexto: uma abordagem sociocognitiva. Trad. de Rodolfo Ilari. São Paulo: Contexto, 2012. 


\section{Anexo}

1. Pai, afasta de mim esse cálice

2. Pai, afasta de mim esse cálice

3. Pai, afasta de mim esse cálice

4. De vinho tinto de sangue

5. Como beber dessa bebida amarga

6. Tragar a dor, engolir a labuta

7. Mesmo calada a boca, resta o peito

8. Silêncio na cidade não se escuta

9. De que me vale ser filho da santa

10. Melhor seria ser filho da outra

11. Outra realidade menos morta

12. Tanta mentira tanta força bruta

13. Como é difícil acordar calado

14. Se na calada da noite eu me dano

15. Quero lançar um grito desumano

16. Que é uma maneira de ser escutado

17. Esse silêncio todo me atordoa

18. Atordoado eu permaneço atento

19. Na arquibancada pra a qualquer momento

20. Ver emergir o monstro da lagoa

21. De muito gorda a porca já não anda

22. De muito usada a faca já não corta

23. Como é difícil, pai, abrir a porta

24. Essa palavra presa na garganta

25. Esse pileque homérico no mundo

26. De que adianta ter boa vontade

27. Mesmo calado o peito resta a cuca

28. Dos bêbados do centro da cidade

29. Talvez o mundo não seja pequeno

30. Nem seja a vida um fato consumado

31. Quero inventar o meu próprio pecado

32. Quero morrer do meu próprio veneno

33. Quero perder de vez tua cabeça

34. Minha cabeça perder teu juízo

35. Quero cheirar fumaça de óleo diesel

36. Me embriagar até que alguém me esqueça.

Chico Buarque

Recebido em 18/12/2013. Aprovado em 27/02/2014. 